\title{
Morphology of House Pattern in Tenganan Dauh Tukad Village, Karangasem
}

\author{
Ngakan Ketut Acwin Dwijendra ${ }^{1}$ \\ ${ }^{1}$ Architecture Department, Engineering Faculty \\ Udayana University \\ Bukit Jimbaran, Badung Bali \\ E-mail: acwin@unud.ac.id
}

\begin{abstract}
Traditional Settlements Tenganan Dauh Tukad Traditional Village, Karangasem regency, has a uniqueness of traditional dwelling patterns that become a local character of the region. However, along with the development of tourism in this village, the traditional settlement is not only a pride, but also the object of commodification. This is an interesting phenomenon where on the one hand, people try to maintain their traditional residential identity to attract tourists visiting, but, on the other hand, they change their dwelling as a tourism facility. The change is a challenge and a pressure for maintaining the traditional configuration as an identity. This is a phenomenon of conflict in the development of a cultural tourism area. On the one hand, tourists expect a natural and original nature and culture. On the other hand, society and culture change as the society interacts with the outside culture and the desire to accommodate the needs of the visiting tourists. Therefore, the purpose of this study was to investigate the paradoxical phenomenon of changes in the morphology of residential patterns in Tenganan Dauh Tukad Village and explore the conflict between conservation of traditional housing character and tourism demand. By conducting field studies (measurements), of selected stratified random sampling houses, and interviews, to examine the impact of changes on values and their meanings, this study will discuss changes in the physical configuration, meanings, and values of a traditional house. This research will explore the original roles and meanings of altered housing that can still be maintained and the new roles and values contained in the new configuration. In this study will also discuss the impact of new values on the meaning and value of the original configuration. With the identification of the morphologic character of the residential pattern, it is expected to be a model of change and provide an appropriate perspective for the community, the government and the tourism actors in transforming the traditional housing in Tenganan Dauh Tukad Village, Karangasem Regency.
\end{abstract}

Keywords: morphology, traditional, house, culture, tourism.

\section{INTRODUCTION}

\section{A. Background}

The traditional settlement of Tenganan Dauh Tukad Traditional Village, Karangasem Regency, has a unique spatial configuration of traditional residential patterns that become the local identity of the region. However, along with the development of tourism in this village, the traditional settlement is not only a pride but also the object of commodification. Increased tourist visits encourage the development of tourism facilities that resulted in changes in the configuration of traditional village space Tenganan Dauh Tukad Village. This is an interesting phenomenon where on the one hand, people are proud and try to maintain their traditional residential areas and patterns to attract tourists visiting, but, on the other hand, they change their occupancy patterns as tourism facilities. The focus of this phenomenon is that changes in occupancy patterns indicate a great challenge in the era of economic tourism in maintaining the authenticity of the spatial configuration of housing as an expression of cultural identity.

The pattern of settlements Tenganan Dauh Tukad Village closely related to the cultural philosophy, namely the cultural philosophy of Bali is the concept of Rwa Bhineda, Tri Hita Karana, and Tri Mandala, which is manifested into the concept of spatial cultural preservation area Tenganan Dauh Tukad Village. But tradition is not static where a tradition undergoes a gradual process of change [6] [8] [9] [10] [11] [20]. A tradition does not simply repeat the previous tradition, but is a selective process of adopting new things. A new tradition will undergo a screening process, adjustments, and modifications tailored to the existing needs [2] [5] [7] [17] [18] [23] [25]. The interaction of people with outside cultures influences the process of receiving new traditions in a society [14] [15]. The focus of this discussion is the discussion of the dynamic cultural change in anticipating the impact of 
tourism. The change is a challenge and a pressure for maintaining the traditional configuration as an identity. As a researcher in the field of architecture, social, culture, and tourism building, the research team was able to describe the existing problems and identify and assess the phenomenon of morphological changes in traditional shelter patterns as a response to maintain local identity and meet tourism challenges [2] [13] [14] [21].

\section{B. Research Question}

From the above background can be raised the problems faced by Tenganan Dauh Tukad Village, Karangasem are as follows:

1. What is the development of the morphology of residential patterns from the Tenganan Dauh Tukad Village?

2. How does the configuration change affect the values and meanings of the original configuration of the occupancy pattern as well as the factors behind the change?

\section{Research Objectives}

This change is a challenge for public and government efforts to maintain the natural conditions, culture, and traditions of the people who are the tourism development resources. On the other hand, society and culture change as the society interacts with the outside culture and the desire to accommodate the needs of the visiting tourists.

Therefore, the purpose of this study are:

1 Investigating the paradoxical phenomenon of changing the development of residential patterns in this village, what is the true pattern of the original dwelling? The extent to which changes in the morphology of the occupancy pattern and their development and what are the factors causing the morphology, to explore the new roles and values contained in the new configuration and also discuss the impact of new values on the meaning and value of the original configuration. So this research explores the conflict between the importance of conservation of traditional housing character and the demands of tourism.

2 This study is dedicated to provide guidance on how to make a housing change as a response to meet the needs of tourism and conservation interests of traditional residential areas.

\section{Outcome Targets and Research Benefits}

The emphasis of the study to be examined is on the transformation of occupancy-based traditional morphology types that are occupied with the changes in demography, lifestyle changes and the development of tourism. The transformation of the typology of residential morphology is a process of change (as a distinguishing element), as well as existence (as a fixed element) occurring at home, in accordance with applicable architectural principles. The targets and outcomes of residential transformation research of Tenganan Dauh Tukad Traditional Village, Karangasem Regency are:

1. The original morphological type of housing.

2. Changes in occupant characteristics associated with morphological type transformation.

Furthermore, this research is expected to provide great benefits and contribution for both government and society such as:

1. To contribute beneficial to the community and implement the policy of tourism development which is one of the national development priority programs.

2. To contribute theory about the transformation of traditional housing in Tenganan Dauh Tukad Village, Karangasem.

3. To be used as a foundation to determine the direction of development of conservation program of traditional residential building of world cultural heritage area of Tenganan Dauh Tukad Village, especially in Bali, and Indonesia in general.

\section{E. Literature Review}

Tradition is classically defined in the 1950s and 1960s as static, with little innovation based on the elite tradition of tradition in a society. Nevertheless, today, tradition is not always a static phenomenon but a gradual transformation process [8] [24] [26]. The idea of a tradition is very accommodating that can be transformed in an intergenerational transmission process. This transmission process refers to ideas from human responses to old traditions with little or no change [16] [19] [22].

There are several kinds of things that affect the transformation [13] [14] [21], that is:

1. Technology caused by all aspects of life involves technology.

2. Lifestyle and demography, with the influence of time and changes in job classification, age, and status level influences.

3. Politics is closely related to the policy of the holder of power.

4. The economic view of the conditions and developments in the field of community business.

Using the theories of transmission of the tradition above, the notion of transformation is a housing production and the architecture and traditions within it are being explored to understand how communities construct their homes and housing as a physical form of culture, as a response to new conditions and to show their identity.

\section{RESEARCH METHODS}

The type of research conducted is explorative descriptive that is research that is digging and telling or describing a phenomenon in a non-experimental way, consisting of the following stages:

\section{A. Data Collection Stages}


Fig. 2. Morphological Pattern of Tenganan Dauh Tukad Village, Karangasem

The uniqueness of yard pattern in Tenganan Dauh Tukad Village, Karangasem as shown in Figure 3 are:

1. A residential pattern in Tenganan Dauh Tukad settlement has characteristic of traditional settlement of plot of natah pattern with sanga mandala concept which is formed from sanggah, bale dangin, bale daja/meten, middle bale, bale dauh, and pawon.

2. Sanggah, is a place of family worship mainly to the ancestors and God Ida Sang Hyang Widhi.

3. Bale Dangin, is a place to hold a religious ceremony, as a bed of grandparents and can also be used to store ceremonial means/equipment. Bale dangin is typically six with a long rectangular plan, one or two sides (kangin and kelod) covered by a wall while the other side is open.

4. Bale Daja/Meten, serves as a place to sleep and store valuables/heirlooms. The shape of the rectangular metallic bale plan consists of eight columns and there are also 12 poles. The four sides are covered with walls.

5. Pawon: because the mountain area is cold enough, the pawon that serves as a place to cook and work for women contains bale (bed) and preparations to make materials offerings / banten. Pawon is usually sixmasted and surrounded by walls on all four sides.

6. Bale Dauh, serves as a workplace during the day, and bed at night. Bale dauh had a six-poster and was surrounded by a wall. Side facing the open (no walled) tab.

7. Bale Tengah, is a place to hold a religious ceremony. Bale is a six-capped with a closed on one side of the north side.

8. Angkul-angkul, serves as the entrance. The settlements in the core area of the village have two types of angkul-angkul namely angkul-angkul as the entrance of the main shaft and angkul-angkul as the entrance from the shell to the yard of the house. While in the development area only has one angkul-angkul.

\section{B. Discussion}

\section{Morphological Changes in House Patterns}

The transformation of the traditional house in Tenganan Dauh Tukad Village, Karangasem was identified by comparing the object of research with a traditional house which still shows its original shape. Categorization is done to indicate the rate of change of transformed residential units. Below is Table 1 which shows the relationship of categories of residential units with the intensity of transformation in Tenganan Dauh Tukad Village, Karangasem are:

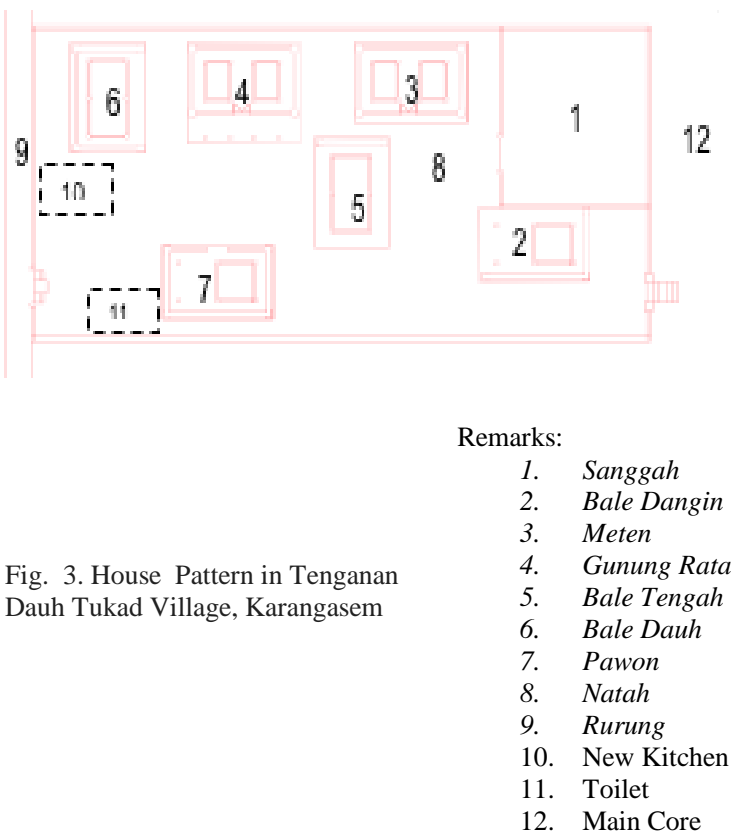

1. Category A: Intensity of Transformation of Small House Units. It can be reviewed based on aspects of material change and shape, functional changes, and the absence of new space in one plot.

2. Category B: Intensity of Transformation of House Unit Simply, including the existence of material and shape changes, while the function of fixed space, and no new space in one lot.

3. Category C: Intensity of Transformation of Multiple House Units. These include material and shape transformations, space/fixed function transformations, and there is new space in one lot.

4. Category D: The Intensity of Transformation of Huge House Units. Transformation involves the transformation of material and form, function transformation, existence of new space with new function.

Based on the categorization of the transformation of the above house units, the transformation of house units is categorized into four types (Table 1) such as:

1. Category A - Original House - Little Change - 7 Houses

Category A occupancy is the least transformed occupancy, even this dwelling has not undergone a transformation at all.

The pattern of fixed space, the form of the house (proportion and size) is fixed, and still use the original material that is the roof of the reeds, the roof structure, and wooden pole. The walls of compacted soil, the floor in the form of compacted soil or hardened with a flat stone. 
TABLE 1. CATEGORIZATION OF HOUSE TRANSFORMATION

\begin{tabular}{lllll} 
& & & \\
\hline Morm & Constant & Change & Change & Change \\
Function & Constant & Change & Change & Change \\
Spatial Pattern & Constant & Constant & Change/Constant & Change \& New \\
\hline
\end{tabular}

Source : Manik (2007).

\section{Category B - Enough Changes - 22 Houses}

Category B occupancy undergoes a transformation of material and form, while function and layout tend to remain the same as the original state. Changes are mainly the use of materials for floors, walls, and roofs. Changes lead to the use of more practical materials, saving on costs, time and effort. Changes also occur with the addition of new buildings that occupy vacant land around the house so as not to change the existing mass patterns and forms of natah that is traditionally very useful at the time of religious ceremonies,

Fixed spatial pattern, fixed house shape while the material used in accordance with the development of zinc roof, asbestos or tile; masonry or brick walls, the floor is plastered.

\section{Category C - Many Changes - 31 Houses}

The visually visible transformation of Category $\mathrm{C}$ occupancy is in the material, building form, spatial function, and spatial pattern. The average occupancy category $\mathrm{C}$ adds new buildings as well as changing the shape of new buildings by adding new functions to the building. The shape of a new building that is influenced by the forms of modern buildings that are usually called office bale.

The pattern of fixed space, the shape of the house changed most of the changes occurred in bale daja and bale delod which is used as a sleeping room. In addition, there are also additional new functions such as bathrooms, additional kitchens and stalls. But sanggah, bale dangin that is used for ceremony and pawon usually remain. The use of the material also changes the roof of zinc, asbestos or tile; masonry or brick walls, floor plastered or with ceramic finishing.

\section{Category D- Very Many Changes - 13 Houses}

Transformation of Category D occupancy includes the development of both the basic pattern of residential units, the shape and use of materials. But the fixed element in this type of D house is bale gede building, because its function is very complex. Bale gede is functioned as a place to receive guests, place of execution ceremony manusa yadnya and pitra yadnya especially at the time of death, bale gede has a big role as place when doing yadnya.

The pattern of space, the shape of the house, and the material changes and more to the modern building which consists of a period that accommodates all the functions that exist. But what remains is sanggah and bale dangin.

\section{Factors Cause Occurrence Morphological Change Occupational Patterns}

The construction of infrastructure to facilitate the flow of transport of agricultural products and plantations outside the village affects the need for adequate means of transportation. Ownership of motor vehicles will certainly demand a space that is a garage, both temporary and permanent. In addition, tourism activities around the area led to the start of facilities and infrastructure supporting tourism such as shops and shops that affect the transformation of traditional homes.

The development of activities requires the transformation of residential units functions. The enclosed space traditionally only functioned as a bed, is now also used as a dining room and family room. The joint activity that was initially carried out on the terrace and the yard have now entered into an enclosed space. It shows the occupants increasingly need private space as a means to express themselves respectively. Built-in office bale is one example. Bale office that has a family room and additional sleeping space indicates there has been a transformation function of residential units. The reason for the fulfillment of space needs is closely related to the increasingly complex activity patterns along with the development of the era. Transformation of activity patterns refers to the increasingly complex lifestyle of the inhabitants.

Some changes to the transformation and its causal factors can be described as follows:

1. Material Changes - Technological Factors, Economics, Lifestyle/Socio-Culture. Along with the development of the era, building technology found more sophisticated so mass produced, the use of traditional materials (wood, alang-alang and land popolan) began to be reduced even no longer exists.

2. Shape Changes - Technological Factors, Economics, Lifestyle/Social Culture. The shape of the shelter is more affected by the transformation of building materials, such as the change of the roof slope due to the use of tile and zinc, the use of stone material makes possible the manufacture of carved stone and the use of ceramics for the floor display bright colors.

3. Spatial and Spatial Changes - Demographic, Economic, Lifestyle/Socio-Cultural Factors. The enclosed space traditionally only functioned as a bed, is now also used as a dining room and family room. The joint activity that was initially carried out on the terrace and the yard have now entered into an enclosed space. 


\section{CONCLUSION}

Based on the above results and discussion can be summarized as follows:

1. There has been a transformation of residential units in Tenganan Dauh Tukad Village, Karangasem where changes from only a few (Category A) to very large changes (Category D), from material changes (Category B) to spatial changes (Category D).

2. Factors that cause transformation is due to technological progress factors, demography, lifestyle, socio-cultural and economic.

Some suggestions that can be formulated are as follows:

1. Conservation needs to be done to maintain the existing potential, as well as to be able to support the development according to the potential possessed by this region. The proper form of preservation in Tenganan Dauh Tukad Village, Karangasem is in the form of conservation, preservation and revitalization. Conservation is applied to the visual aspect of components such as protection forests and temples, paddy fields and terraces. Preservation is applied to aspects of temple, village pattern, bale banjar, bale desa; Functional aspects such as land use and circulation: visual aspects such as structure and pattern of natah.

2. Need to be done an arrangement of residential areas and units so that the transformation does not change the meaning and values contained in the spatial area. It needs to be formulated model design or home prototype as guide/reference/model for residents in transforming their home in Tenganan Dauh Tukad Traditional Village, Karangasem.

\section{ACKNOWLEDGMENTS}

Acknowledgments to those who have supported the writing of this paper are LPPM and the Faculty of Engineering Udayana University for the support of research grants and Village Head and all communities and respondents Tenganan Dauh Tukad Traditional Village, Karangasem.

\section{REFERENCES}

[1] Brubaker, R \& Cooper, F (2000) 'Beyond identity', Theory and Society, vol. 29, no. 1, pp. 1-47.

[2] Clifford, J (1994) The predicament of culture: twentieth-century ethnography, literature, and art, Harvard University Press, Cambridge.

[3] Covarrubias, M (1974) Island of Bali. Kuala Lumpur: Oxford University Press.

[4] Derek \& Japha, V (1991) 'Identity through detail: an architecture and cultural aspiration in Montagu, South Africa, 1850-1915', TDSR, vol. II, pp. 17-33.

[5] Dharmayuda, IMS (1995) Kebudayaan Bali: pra Hindu, masa Hindu dan pasca Hindu. Denpasar: CV Kayumas Agung.
[6] Dwijendra, NKA (2008) Arsitektur Rumah Tradisional Bali, Berdasarkan Asta Kosal Kosali, Denpasar: Udayana University Press.

[7] Dwijendra, NKA (2009) Arsitektur Kebudayaan Bali Kuno, Denpasar: Udayana University Press.

[8] Eiseman Jr, FB (1989) Sekala and niskala: essays on religious, ritual and art, vol. I, Periplus Editions, Singapore.

[9] Ferschin, P \& Gramelhofer, A (2004) 'Architecture as information space', Proceedings of the Eighth International Conference on Information Visualisation (IV'04).

[10] Hobart, A, Ramseyer, U \& Leemann, A (2001) The people of Bali. Massachusetts: Blackwell Publishers Ltd.

[11] Hall, S (1990) 'Cultural identity and diaspora', in J Rutherford (ed), Identity, community, culture difference, Lawrence and Wishart, London, pp. 222237.

[12] Hobart, M (1978) 'The path of soul: the legitimacy of nature in Balinese conceptions of space', in G Milner (ed.), Natural symbols in South-East Asia, School of Oriental and African Studies, London, pp. 5-28.

[13] Hoben, A \& Hefner, R (1991) 'The integrative revolution revisited', World Development, vol. 19, no. 1, pp. 17-30.

[14] Hobsbawm, E. (1983) 'Introduction: inventing traditions', in E Hobsbawm \& F Ranger, (eds), The invention of tradition, Cambridge University Press, Cambridge, pp. 1-14.

[15] Kagami, H (1988) Balinese traditional architecture in process, Inuyama: the Little World Museum of Man.

[16] Lozanovska, M (2011) 'Holy days after migration', 2nd International Conference on Intangible Culture, Green Lines Instituto, Barecelos, pp. 459-469.

[17] Mantra, IB (1993) Bali masalah sosial budaya dan modernisasi. Denpasar: Upada Sastra.

[18] Nordholt, HS (1986) Bali: colonial conceptions and political change 1700-1940 from shifting hierarchies to 'fixed' order, Rotterdam: Erasmus.

[19] Picard, M (1996) Bali: cultural tourism and touristic culture. Singapore: Archipelago Press.

[20] Poerwadarminta, WJS (1989) Kamus Besar Bahasa Indonesia. Jakarta: Balai Pustaka.

[21] Proshansky, HM et al. (1983) 'Place identity: physical world socialization of the self', Journal of Environmental Psychology, vol. 3, pp. 57-83.

[22] Putra, IDGADP (2015) 'The impact of tourism on the transformation of the tradisional Balinese house, unpublished PHD thesis, Melbourne: Deakin University Australia.

[23] Shils, E (1971) 'Tradition', Comparative Studies in Society and History, vol. 13, no. 2, Special Issue on Tradition and Modernity, pp. 122-159. 
[24] Swellengrebel, JL (1984) Introduction, in JL Swellengrebel (ed), Bali: studies in life, thought, and ritual, Foris Publication Holland, Nethelands, pp. 176.

[25] Wikstrom, T (1995) 'The home and housing modernization', in DN Benjamin, The home: words, interpretations, meaning and environment. Avebury: Aldershot.

[26] Wood RE (1993) 'Tourism, culture and the sociology of development', in K Hitchcook \& Parnwell (eds), Tourism in South-East Asia, Routledge, London, pp. 48-70. 